\title{
The Participation of Community in Tourism Development of the Muara Jambi Temple Complex, Muaro Jambi Regency
}

\author{
Tirta Utama Sinuhaji ${ }^{1}$, Suwardi Lubis ${ }^{2}$, Asfriyati $^{2}$ \\ ${ }^{1}$ Master Student in Universitas Sumatera Utara, Medan, Indonesia \\ ${ }^{2}$ Lecturer in Universitas Sumatera Utara, Medan, Indonesia \\ Email : nrlamaliah@gmail.com
}

\begin{abstract}
s :
The Muarajambi area is a national cultural preserve with an area of 3,981 hectares covering 9 villages in 2 sub-districts. This area has quite promising tourism potential. Tourism activities in the Muarajambi Temple area are centered in Muara Jambi Village. This is due to the fact that most of the restored temples are in this area. around the main temple complex. The development of tourism is pursued by the community by forming associations and organizations, so that it can help in developing tourism in the Muarajambi Temple area. Community participation in developing tourism in the Muarajambi Temple Area is mostly done through tourism conscious groups; in general community participation is influenced by two factors. The first factor is an internal factor, internal factors that influence the Group includes a strong desire of the community to participate, a sense of concern for Group members towards the younger generation, the age of the members involved in these groups are in the productive age, and the level of education of the management also influences their participation under construction. The second factor is an external factor, an external factor that influences community participation in tourism development in the Muara Jambi village, including the large support from the government regarding community involvement in activities that support tourism. However, the role of the Muaro Jambi Regency Government which has full authority over the development of this region has not yet had an influence in the process of developing the Muarajambi Temple Area.
\end{abstract}

Keywords :

community participation; tourist destinations; muarajambi temple area

\section{Introduction}

As an ancient relic, Muarajambi Temple offers three forms of attraction. First, when visiting the Muarajambi Temple, tourists can enjoy the remnants of the grandeur of 11 Buddhist temples from IV and V centuries. The Chinese War Gong, Chinese currency, Jagopati statue and hundreds of other ancient objects exhibited at the Jambi State Museum are added values to attract tourists. Not only that, the ancient natural embankment stretching along the $8 \mathrm{~km}$ in the area of the site offers a unique for visitors. This natural embankment is able to protect the Muarajambi temple from major floods which always hit the surrounding area due to the overflow of the Batanghari River.

Secondly, Muarajambi Temple is located in a residential area of the Jambi Malay community so that tourists can see the daily life of the indigenous people. Most people convert to Islam with their main livelihoods in the rubber and palm oil plantation sector. Third, Muarajambi temple is the location of several cultural celebrations / festivals in Jambi Province. Two of them are the Vesak Festival by Buddhists and the Muarajambi temple Festival which is held every year. Tourists can not only enjoy these events, but they can also take part in Durian Hunting Tours held by the Muarajambi Youth Creation Center every durian season at the Muarajambi temple Complex 
Table 1.1 Attractions of the Muaro Jambi Temple Tourism Area

\begin{tabular}{|l|l|l|}
\hline No & Attractiveness & Tour Type \\
\hline 1 & Temple Building & Cultural / Historical Tourism \\
\hline 2 & Cycling & Artificial Tourism \\
\hline 3 & Duku Plantation & Agro Tourism \\
\hline 4 & Museum / Collection Building & Cultural / Historical Tourism \\
\hline 5 & Durian Plantation & Agro Tourism \\
\hline 6 & $\begin{array}{l}\text { Traditional Population } \\
\text { Settlements }\end{array}$ & Cultural / Historical Tourism \\
\hline 7 & Festival / Performing Arts & Cultural / Historical Tourism \\
\hline
\end{tabular}

Source: Processed Primary Data, 2019

\section{Review of Literature}

\subsection{Community Participation}

Participation comes from English language that is "participation" which means taking part participation of John M Echols \& Hasan Shadily (1976). In the big Indonesian dictionary, it is explained that participation means participating in an activity. In general, the definition of community participation in development is the participation of all members or representatives of the community to participate in the development process, including deciding on plans to be implemented, benefits to be obtained and how to implement and evaluate the results of their implementation.

Canter (1981) defines participation as feed-forward information and feedback information. With this definition community participation as a continuous two-way communication process can be interpreted that community participation is communication between the government as the policy holder and the community on the other party as the party who feels the direct impact of the policy. From Canter's opinion, it is also implied that the community can provide a positive response in the sense of supporting or providing input to programs or policies taken by the government but can also reject policies.

Adisasmita (2006) provides an understanding of community participation is the involvement of community members in development, including activities in planning and implementing development programs carried out in local communities. Participation in development is an actualization of the willingness and ability of community members to sacrifice and contribute to implementation program implemented. Increasing community participation is one form of active community empowerment oriented towards achieving the results of development carried out in the community. With the participation of the community, development planning is strived to be more directed, meaning that the development plan or program prepared is in accordance with what is needed by the community, meaning that in the preparation of development plans / programs priority is determined, thus the implementation of development programs will also be carried out effectively and efficiently. 


\subsection{Tourism}

Some experts put forward the notion of tourism with different boundaries. As the definition of tourism according to Nyoman S. Pendit is as follows: "Tourism is one type of new industry that is able to produce rapid economic growth in the provision of employment, increased income, living standards and stimulates other productivity sectors" (Pendit, 1999).

According to Salah Wahab, the understanding of tourism is one of the new style industries that is able to make rapid economic growth in terms of employment opportunities, income, standard of living, and in activating other production sectors in tourist-receiving countries. In addition, tourism is also a complex sector, covering industries in the classical sense, such as the handicraft industry and the souvenir industry. Lodging and transportation are also economically seen as industries. (Salah Wahab, 1996)

Cultural tourism is a travel activity carried out by a person or group by visiting a particular place for recreational purposes, personal development, or studying cultural attractiveness by utilizing the cultural potential of the place visited. Tourism Culture of tourism which intends to enrich information and knowledge about other countries and to satisfy entertainment needs. This includes visits to exhibitions and fairs, traditional celebrations, places of nature reserves, ancient reserves and others.

Tourism is also an industry that is able to produce rapid economic growth in providing jobs, increasing income and living standards. As a complex industry, tourism also supports other sectors such as lodging, transportation and handicraft and souvenir industries. (Amir wahyu, 2019)

According to Higgins (2019) tourism in order to place the rights of local communities above the rights of tourists for holidays and the rights of tourism corporate to make profits.

\subsection{Community Based Tourism Development}

In the development of community-based tourism can refer to the philosophy of sustainable tourism development which emphasizes that building tourism is not for the benefit of tourists, but to build tourism for the interests of the people that tourists need. Thus, the community-based tourism approach can better ensure the interests of the community. Community-based tourism (Community Based Tourism) was developed based on the principle of balance and harmony between various stakeholders in tourism development including the government, private sector, and the community. Ideally this development principle emphasizes the development of the community by the community and for the community which starts from the development stage, from planning, development, management and development to monitoring and evaluation which must actively involve the local community.

Community-based tourism is an economic activity that if properly developed can overcome a number of development challenges, including poverty reduction, local economic development, peace, and community harmony and sustainable management of natural resources and the environment. This approach is an alternative for tourism development that benefits local communities and ensures the sustainability of tourism. Local people are the main beneficiaries of local tourism activities. Besides that the Community Based Tourism model is very suitable for the preservation of local resources both natural and cultural resources.

\subsection{Area Development}

According to Law Number 26 of 2007 concerning Spatial Planning, a region is a space which is a geographical unit and all related elements whose boundaries and systems are determined 
based on administrative and / or functional aspects. Sirojuzilam and Mahalli (2010) region is a group of regions which are located close together and inhabited by a number of residents over a certain territorial or space. In summary, the concept of space or region is marked by the absolute location and distribution of areas of certain images on the surface of the earth.

In general the area is divided into 3 parts, namely:

a) Homogeneous region, is an area where economic activities prevail in various corners of space has the same characteristics, among others, in terms of per capita income of the population and in terms of economic structure.

b) Nodal region, is an area as an economic space controlled by several economic actors.

c) Administrative region, which is based on the division of government administration (Sirojuzilam and Mahalli, 2010).

By understanding the regional concept, it is expected that planners will take an approach to pay more attention to the components of the regional arrangement that interact with each other and combine the potential of each component so as to create a good and directed regional development and development strategy. Development can be interpreted as an activity to add, improve, improve or expand. The concept of regional development in Indonesia was born from an iterative process that combines the basics of theoretical understanding with practical experiences as a form of its dynamic application (Sirojuzilam and Mahalli, 2010).

Sirojuzilam (2005) area development basically means increasing the value of the benefits of the area for the people of a certain area to be able to accommodate more inhabitants, with an average level of community welfare with a lot of facilities or infrastructure, goods or services available and community business activities that are available increased, both in terms of type, intensity, service and quality.

\section{Research Method}

This study focuses on analyzing Community Participation in the Muarajambi Temple Complex and the impact of community participation on the preservation of cultural heritage objects in the Muara Jambi Village.

\subsection{Types of research}

This research was conducted using qualitative methods by looking at community participation in the process of tourism management and development in the Muarajambi area and the impact of participation on the preservation of cultural heritage objects. This study uses a qualitative procedure in which the theory does not function as the concepts being tested, but rather as a means of sharpening data analysis (Muhadjir, 1989).

Qualitative research can also be understood as research from the bottom, so that data and data sources can develop at any time in the research process. Judging from the data presentation technique, qualitative research uses descriptive patterns. Descriptive pattern as mentioned is a research method that tries to describe and interpret objects according to what they are (Sukardi, 2009). So in conducting research, the writer uses a descriptive qualitative study, because in this way a fundamental picture of the development of the mind, ideology, and values of the social structure that develops will be obtained.

This study took place in Muarajambi Temple Tourism Object located in the village of Muara jambi, Maro Sebo District, Muaro Jambi Regency. Researchers chose this location because 
Muarajambi Temple is a cultural attraction that has an attraction that is not shared by other temples. It also contributes sufficiently to income in the tourism sector and to the people who are around the bathing complex.

\section{Discussion}

\subsection{Community Participation in Tourism in the Muara Jambi Temple Area}

In developing a tourism area it takes cooperation from various parties not only to rely on the local government but also there must be community cooperation in developing a tourist destination. A tourist destination is inseparable from the surrounding population as the host, both in its management and development so that people feel the impact of the existence of tourism in their area.

The participation of the surrounding population indicates the support of the community for the development of existing tourism. The role of the population that is needed in tourism development is public awareness that tourism can improve the economy and welfare. When the surrounding population has felt the impact of welfare from tourism, the sense of care and sense of belonging to the tourist attraction in the area also increases.

Community participation can also be seen from the response of the local community to the existence of tourist destinations in the region, with the high response of the population will accelerate the development of tourism by conducting socialization and training from relevant parties, so that the community can improve the welfare of tourism. There is a need for guarantees, supervision, and socialization of related parties to preserve historical buildings as well as supervision of the impact of tourism on the community. This community response was explained by Datuk Abuzar as the Head of Muara Jambi Village:

"....with the establishment of an integrated tourist area in Muara Jambi, most of the people here strongly agree with the determination so that it can provide additional income for the people who have been dependent on gardening for their livelihoods. Therefore, with the tourist attractions here, the community can increase their income by doing various activities around the temple. Besides that, the temple area is also often held a diversity of events by Buddhists, although in our village the majority is Muslim the village community is very respectful and helpful when there are like the Vesak events held every year ..."

With the magnitude of the community's response to the Muarajambi Temple area, the development planned by the government and tourism institutions in the region can run well, the community's excellent view of tourism in the Muarajambi Temple occurs because the local community has felt the impact of the destination in the Muara Jambi village area. In addition to the excellent response to tourism, the residents of Muara Jambi Village also respected the Buddhist religious event which held worship in the Muarajambi Temple area.

\subsubsection{Population Participation in Tourism Institutions}

The development of a tourism destination is inseparable from the participation of the community, especially community organizations that support tourism, such as the Tourism Driving Group which is in direct contact with the tourism process and surrounding communities. In the development of community-based tourism, the involvement of local communities is one of the important keys in the success of tourism activities. This can happen if the community has been 
involved from the beginning and is given space to participate in planning to the end of a development program.

Community-based tourism development can be seen from the Village Ecotourism Network (JED) based in Bali, this institution provides learning how a community-based tourism approach can be carried out in the assisted villages facilitated by the Wisnu Foundation. Since the 90s, several villages in the program area have started ecotourism development through the development of attractions based on local resources.

The existence of a tourism driving group makes it easy for the community to be coordinated and guided for tourism development. Like the process of developing attractions, marketing packages to learning about guest management and accommodation. In addition, with this tourism mobilization group, people can be given knowledge to be aware of and care for the preservation of cultural heritage in the region. The following are community organizations in Muarajambi region:

\section{- Padmasana Foundation}

Padmasana Foundation is a non-profit organization which is collaboration between Macro Film International, Dwarapalamuja and Saramuja. Be open, non-governmental and community based not bound to religion. The establishment of this foundation makes anyone and any background can join on the basis of concern for the Mauarajambi District. The diverse backgrounds of members make Padmasana a place for sharing knowledge that is dominated by each member.

The following are the organizations that the Padmasana Foundation collaborates on:

- Dwarapala Muja

Dwarapala Muja is a youth organization in Muaro Jambi Village, which was born out of a concern for the Muarajambi District. This organization is also often involved in being a local force by researchers both from within the country and abroad, thus providing direct education about the Muarajambi Area. Dwarapala Muja invites the public through socialization in order to know the importance of preservation and improvement of community welfare through tourism in the Muarajambi District.

- Alam Raya School (Saramuja)

Alam Raya School of MuaraJambi is a non-formal educational forum for children of elementary schools in MuaraJambi Village. The establishment of this school in February 2010 by the formation of a number of youths in Muara Jambi Village was based on a sense of concern for the world of education, with the establishment of this educational forum it was hoped that in the future it could be a place for young people to add knowledge or awareness to preserve the environment and instill concern for history.

At Alam Raya School of MuaraJambi, students are directed to be able to learn to build a sense of togetherness, conduct discussions about environmental preservation, history, culture and other general knowledge. In addition to the theory, students are also invited to carry out activities such as greening, cleaning the environment, developing creativity and holding field studies. The Alam Raya School uses study patterns in the studio and outdoors on holidays such as Sundays. Saramuja itself has the motto "Everyone is a Teacher, Alam Raya school", with this motto, the teaching staff apart from the youth of MuaraJambi Village also involved the student activity units of several universities in Jambi, the community who wanted to share their knowledge and anyone who wanted to share knowledge. The students of Saramuja are also often involved in cultural events 
at Muarajambi Temple, such as presenting traditional dance, poetry, singing folk songs and other cultural activities.

The existence of this system, helped in the development of tourism, environmental preservation and historical knowledge of the surrounding community. Through your scholarship it helps educate the surrounding community to care about how important it is to preserve cultural and historical heritage objects.

\section{- Macro Films International}

Macrofilm International is a creative production house to produce original, innovative and artistic audio-visual works. Always trying to turn creative ideas into a great work, high artistic value and interesting to enjoy. Various forms of audio visual works that are produced have a variety of types, including corporate videos (company profiles, video campaigns etc.), tvc (commercial, features, documentaries, bumpers, etc.) as well as music videos. With the dedication, experience and professionalism it possesses, MFI always strives to make each work that is produced has a unique, valuable and quality character.

The existence of MFI helps the development of Candi Muarajambi tourism, MFI helps promote tourism by making a tourism profile video both in the Muarajambi area and tourist attractions in Jambi Province. Tourism profile videos are also played in the midst of the community through step-by-step with the aim of educating the neighboring community of Muarajambi District. The following program activities carried out at Padmasana Foundation include:

a) Conduct historical research to reconstruct and cultivate Universal Value and Malay History.

b) Collecting objects of cultural heritage found by the community to be examined and preserved.

c) Conduct training and outreach about history and tourism.

d) Become a tourism office partner in organizing tourism events, tourism development and making tourism profile videos in the Jambi area.

e) Propose and assist village officials to make tourism villages.

f) Designing and establishing tourism facilities.

g) Educate children around through the Muaro Jambi Nature School.

h) Helping to find scholarship donors for children around the temple who want to continue their studies in archeology.

i) Building a cultural house (menapo house) in the Muarajambi District.

j) Become a guest speaker in various archeology and tourism seminars.

k) Promote Muarajambi tourism through social media and the internet.

Padmasana Foundation also has a travel agency namely Surya Global Tour (SGP) in collaboration with travel agents from France, Malaysia, Singapore and others, SGP serves a variety of tour packages such as historical, adventure and cultural tourism needed by tourists in the Muarajambi Bathing Area and Other Jambi tours. Every foreign tourist who travels is charged to make a donation to the development of the Muarajambi District, from which the Padmasana Foundation funding activities aside from donors who care about Muarajambi Temple, company CSR funds and event donation tickets when organizing tourism events. Padmasana Foundation also receives funding from the US Ambassador each year starting from 2014 for the cost of developing community education and environmental sustainability.

- Empu Kusuma Circle of Friends 
This association is a gathering of traders formed on the aspirations of traders in the Muarajambi Temple and bicycle renters. This association was formed in 2018 and its formation was also supported by the Cultural Heritage Conservation Center (BPCB). This association has a function to regulate bicycle traders and rental owners in the Muarajambi Temple Area, so that the cultural heritage area can be maintained. The formation of the Empu Kusuma Circle of Friends was also explained by Mr. Ridwan as the Chairman of the Circle of Friends:

"This community is actually formed on the basis of unrest from the Preservation Center for Cultural Heritage that sees the dirty area of the temple as a result of traders selling in the main temple complex that is no longer organized, so we as citizens who sell in the temple complex are gathered to be able to find solutions how to organize the traders so that the temple area is no longer dirty due to the selling of the traders. I, as the head of the association, strongly agree, because the formation of the association also limits sellers who sell in the temple area so that the community around the temple feels secure. This restriction also causes many traders who come from outside this village can no longer sell in the temple area"

From the information delivered by Mr. Ridwan as chairman of the Empu Kusuma Circle of Friends, it can be seen that the involvement of the community around the temple in thinking about the environment of the temple area is an awareness to preserve the cultural heritage. The existence of BPCB as an institution that has the duty to provide protection for the cultural heritage area is in collaboration with the community to deal with the problem of cleanliness of the temple area by encouraging the formation of a community in which there are traders and bicycle rental owners who are aware of the preservation of the Muarajambi Temple complex.

\subsubsection{Community Participation in Tourism Development in the Muarajambi Temple Area.}

The development of a tourist attraction in an area requires seriousness in carrying it out so that the planning carried out in accordance with what is expected, in a development must be supported by various parties who are certainly related to the tourism activity itself, both the private sector, regional governments, especially villages, and related agencies such as the Department Tourism and Culture, Jambi Preservation Hall and other agencies. This manager will later regulate policies and implementation in the field, the government in this case the Office of Tourism and Culture, the Jambi Cultural Heritage Conservation Center, and village and sub-district officials as managers must actively participate in planning, coaching, regulating, implementing, and monitoring. According to Abdul Haviz as chairman of the Jambi Provincial HPI DPP, stated that:

"... the government of Muaro Jambi in particular should try to develop ways to develop the temple area, because so far we in the Muara Jambi village have always worked on their own through organizations and associations that we have established without assistance from the government especially the district. We also in holding events in the temple area the district government never gave support "

In planning tourism development in the Muarajambi Temple Area, a community-based management program must be implemented. The programs needed to develop tourism in the Muarajambi Temple area have been conveyed by the community. The role of government must pay attention to the management program must be community-based, namely management that employs or engages local communities in order to foster a sense of ownership and awareness to take an active role in the development of tourism in their environment. The Office of Tourism and Culture must directly involve the surrounding community such as involving the community in 
tourism events, conducting tourism training and socializing the importance of preservation and community welfare through tourism.

In the process of planning for tourism the community has been involved by the local government, Abdul Havis as Chairman of the DPP HPI Jambi Province explained:

"... How many times have we given advice to the local government, but after that there was no clarity on the program that we have delivered. In fact, if this program runs, we as a local community will definitely help the program to be successful ..."

The ambiguity of the program that was delivered to the local government caused the community to start ignoring the program that was planned to be carried out by the Muarajambi Temple Area.

\section{Conclusion}

The role of the community in the development of tourism is one of the factors supporting the smooth development of a tourist destination. The lack of local government attention has led to the slow development of tourism in the Muarajambi Temple Complex. The existence of a tourism driving group has a significant impact on the development of tourism in the Muarajambi Temple Complex, this group is driven by young people around very helpful to the government in developing tourism, the activities they do such as holding tourism events, proposing tourism villages, opening non-formal schools for children, collecting cultural heritage objects, socializing tourism to the community, conducting research, making tourist videos and others.

1. Public awareness in the Muarajambi Temple Area to the cultural heritage in their village can be seen from the involvement of the surrounding community with events and programs carried out by the MuaraJambi Regency and the Jambi Cultural Heritage Conservation Center. This awareness is not only as a tourism manager but also an awareness of the preservation of existing cultural heritages, this can be seen from the existence of associations that care about the preservation of cultural heritages such as Pemuari MuaraJambi Environmental Care (PPLMJ) besides that the community also collects the leftovers from the temple's remains found in their plantations to be submitted to BPCB.

\section{References}

Adisasmita, R. (2006). Membangun Desa Partisipatif. Graha Ilmu. Yogyakarta.

Ahmad, S.B. 2008. Metode Penelitian. Pustaka Setia. Bandung.

Aprianto, P. 2010. Faktor-Faktor Pendorong dan Penghambat Partisipasi Masyarakat pada Pelaksanaan Program NUSSP di Kelurahan RappociniKelurahan Pannampu Kota Makasar. Universitas Diponegoro. Semarang [Tesis]

Arikunto, S. (2006). Prosedur Penelitian: Suara Pendekatan Praktik. Rineka Cipta. Jakarta.

Bambang, S. (2013). Kebijakan Pembangunan Destinasi Pariwisata konsep dan aplikasinya di Indonesia, Gava Media, Yogyakarta.

Choirinnisa, S. (2010). Evaluasi Pendabuluan terhadap Aspek Fisik dan Kelembagaan Program Pengembangan

Destinasi Percandian Muaro Jambi. Jurnal Ilmu Administrasi dan Organisasi, 170-182.

Davison, G. and C Mc Conville. 1991. A Heritage Handbook. St. Leonard, NSW: Allen \& Unwin.

Deviyanti, Dea. 2013. Studi Tentang Partisipasi Masyarakat dalam Pembangunan di kelurahan Karang Jati Kecamatan Balikpapan Tengah.Universitas Mulawarman. [Jurnal Administrasi Negara] 
Devriyanti, H. (2015). Dampak Pembangunan Parinisata Candi Muaro Jambi terbadap Sistem Mata Pencaharian Masyarakat di Desa Muaro Jambi, Kabupaten Muaro Jambi, Provinsi Jambi. Universitas Andalas. Padang [Skripsi]

Eriansyah, and Rully, F. (2014). Peran Tuo Tengganai dalam Upaya Pelestarian Komplek Percandian Muaro Jambi. Jurnal Ilmu Komunikasi FISIP Universitas Andalas.

Hetifah, S. and Sumarto.(2003). Inovasi, Partisipasi dan Good Governance. Yayasan Obor Indonesia. Jakarta.

Higgins, Freya. (2019). Degrowing tourism: rethinking tourism. Journal of Sustainable Tourism, 2019.

Kusuma, S.T. (1987). Psiko Diagnostik, SGPLB Negeri Yogyakarta. Yogyakarta.

Maifat, S. ( 2011). Partisipasi masyarakat dalam pembangunan pariwisata (Studi tentang pembangunan ekowisata di Kenagarian Lasi Kecamatan Candung Kabupaten Agam, Provinsi Sumatera Barat). Universitas Sumatera Utara. Medan[Skripsi]

Malau, Y.V.(2016). Partisipasi Masyarakat Dalam Pengelolaan Wisata Alam Danau Toba (studi deskriptif di Kelurahan Parapat, Kecamatan Girsang Sipangan Bolon, Kabupaten Simalungun, Sumatera Utara). Universitas Sumatera Utara. Medan[Skripsi]

Moleong, L.J. (2007). Metode penelitian kualitatif. PT Remaja Rosdakarya Offset. Bandung.

Muhadjir, N. (1989), Metode penelitian kualitatif. Rake Sarasin. Yogyakarta.

Ndraha, T. (1991). Dimensi-Dimensi Pemerintahan Desa. Bumi Aksara. Jakarta.

Narudin, D,(2007). Partisipasi Masyarakat dalam Pengembangan Potensi Wisata Bahari Pantai Cermin Kabupaten Serdang Bedagai. Universitas Sumatera Utara. Medan[Tesis]

Nurcholis, H. (2011).Pertumbuhan dan Penyelenggaraan Pemerintahan Desa.Erlangga, Jakarta

Pendit, N.S. (1999). Ilmu Pariwisata Sebuah Pengantar Perdana. PT Pradnya Paramita. Jakarta.

Poernomo, M. (2004). Pembaruan Desa “Mencari Bentuk Penataan Produksi Desa”. Lapera Pustaka Utama. Yogyakarta.

Rahardjo, S. (2013). Beberapa Permasalahan Pelestarian Kawasan Cagar Budaya dan Strategi Solusinya. Departemen Arkeologi Universitas Indonesia.

Sirojuzilam. (2005). Regional Planning and Development. Wahana Hijau. Jurnal Perencanaan dan Pengembangan Wilayah, 11-15.

----- dan Mahalli, K.( 2010). Regional. Pembangunan, Perencanaan dan Ekonomi. USU Press.

Sugiyono. (2006).Metode Penelitian Kuantitatif, Kualitatif, dan R\&D. Alfabeta. Bandung.

----- (2009).Metode Penelitian Kuantitatif, Kualitatif, dan R\&D. Alfabeta. Bandung.

-----(2015).Metode Penelitian Pendidikan (Pendekatan Kuantitatif, Kualitatif, dan R\&D). Alfabeta CV. Bandung.

Sukardi.(2009). Metodologi Penelitian Pendidikan (Kompetensi dan Praktiknya). Bumi Aksara. Jakarta.

Suroso, H., Hakim A., dan NoorI. 2014. Faktor-Faktor Yang Mempengaruhi Partisipasi Masyarakat Dalam Perencanaan Pembangunan Di Desa Banjaran Kecamatan Driyorejo Kabupaten Gresik.Universitas Brawijaya. Wacana, 7-15.

Suwardjoko P.W. and Indira P.W. (2007). Pariwisata dalam Tata Ruang Wilayah. ITB. Bandung. Suwigno. (1986). Administrasi Pembanunan Desa dan Sumber-Sumber Pendapatan Desa. Ghalia Indonesia. Jakarta Timur.

Tanjung, Bahdin, N. and Ardial, (2005). Pedoman Penulisan Karya Ilmiah : Proposal, Skripsi, dan Tesis\} dan mempersiapkan Diri Menjadi Penulis Artikel Ilmiah. Kencana. Jakarta.

Undang-Undang No. 11 Tahun 2010 tentang Benda Cagar Budaya.

Undang-Undang Nomor 26 tahun 2007 tentang Tata Ruang.

Undang-Undang Otonomi Daerah Nomor 32 Tahun 2004

Undang-Undang Negara Republik Indonesia Nomor 32 tahun 2009 tentang Perlindungan dan Pengelolaan Lingkungan Hidup pasal 47

Wahyu, Amir. (2019). Development of Kedah Natural Tourism Object in the Development of Leuser Ecowisata Area in Gayo Lues Regency. Birci Journal, 406-417.

Wahab, S. (1996). Manajemen Kepariwisata. PT Pradnya Paramita. Jakarta 